\title{
Choice of food crops in relation to actual and potential production in the tropics
}

\author{
C. A. de Vries, J. D. Ferwerda and M. Flach ${ }^{1}$ \\ Department of Tropical Crop Husbandry, Agricultural University, Wageningen, The \\ Netherlands
}

Received 30 June, 1967

\section{Summary}

Average world productions of the most important tropical and subtropical root and grain crops are determined and compared. The results are expressed in calories edible per hectare and per day of vegetation. These average world productions are then compared with maximum productions reached in selected experiments in the tropics. Finally the productions are related to the potential production of edible as well as total dry matter. It is concluded that root crops should play an important role in increasing the food production as they have a far higher production of edible calories per day of vegetation, and that these crops should therefore receive much more attention in breeding and selection.

\section{Introduction}

The 'Grow more food campaign' which started in India in 1942 has since become more urgent than ever. For especially in the last years it has become clear that in developing countries a rise in income is not sufficient for stimulating agricultural production. In many of these countries an ever increasing amount of foreign exchange, usually in short supply, has to be used for food imports, thus decreasing the possibilities of industrial growth. Therefore the necessity of a faster increasing food production has received much more attention. In most developing countries, especially in the densely populated ones, 'food' stands for food grains, often even only for rice, and in this connexion it seems important to investigate which crops may give the highest production per unit of surface and of time.

\section{Average production}

From the figures given in the FAO Production Yearbook 1963 the three-year averages of production per unit of surface of a number of tropical and subtropical crops were determined. In order to make these productions mutually comparable, they were expressed in calories edible $(1 \mathrm{Cal}=1000 \mathrm{cal}$. $)$ per period of vegetation and per unit

1 The authors will be very interested in yields, obtained in well conducted experiments and exceeding those mentioned in this paper. 
Table I Average world production of a number of tropical food crops

\begin{tabular}{|c|c|c|c|c|c|c|}
\hline Crop & tons /ha & Cal. $/ 100 \mathrm{~g}$ & $\begin{array}{c}\text { Edible } \\
\text { portion } \\
(\%) \\
(3)\end{array}$ & $\begin{array}{c}\text { Cal./ha } \\
\times \quad 106 \\
(4)\end{array}$ & $\begin{array}{l}\text { Period of } \\
\text { vegetation } \\
\text { (5) }\end{array}$ & $\begin{array}{c}\text { Cal./(ha.day) } \\
\times 103\end{array}$ \\
\hline Rice & 2.0 & 352 & 70 & 5.0 & 150 & 33 \\
\hline Wheat & 1.2 & 344 & 100 & 4.1 & 120 & 34 \\
\hline Maize & 2.1 & 363 & 100 & 7.6 & 135 & 56 \\
\hline Sorghum & 1.0 & 355 & 90 & 3.2 & 135 & 24 \\
\hline Cassava & 9.1 & 153 & 83 & 11.6 & 330 & 35 \\
\hline Sweet potato & 6.5 & 114 & 88 & 6.5 & 135 & 48 \\
\hline Yam & 8.0 & 104 & 85 & 7.1 & 280 & 25 \\
\hline Colocasia & 5.8 & 113 & 85 & 5.5 & 120 & 46 \\
\hline Banana & 21.1 & 128 & 59 & 15.9 & 365 & 44 \\
\hline
\end{tabular}

of surface. This was done with the aid of the tables of Platt (1965). Then the average period of vegetation was estimated and in this way the production of each crop per day of vegetation was determined, which resulted in Table 1.

As the average world productions are mostly calculated from highly divergent figures, especially in the tropics, the value of the estimates given in Table 1 is only very limited. Moreover, the period of vegetation may show large deviations from the figures given in column 5. For instance sorghum and sweet potato have the same average period of vegetation but there are sorghums with a much shorter period of vegetation, whereas sweet potatoes sometimes are harvested after 375 days. Bananas have an average period of vegetation of 420 days, but because a plantation usually is kept up for several years, the production is given per year.

There are, of course, agronomic objections against this method of comparing productions. First this way of calculation is of value only for regions where crops can be grown the whole year round, i.e. subtropical and tropical areas with sufficient water. Secondly no allowance is made for preparation of the soil, which appears the more important the shorter the period of vegetation of the crops is. With rice it should be kept in mind that it usually is transplanted, which means that in the time before transplantation the crop covers approximately $10 \%$ of the surface. Banana, however, occupies the same field for several years.

Despite these limitations Table 1 suggests some general trends. Root crops produce much more bulk than grain crops (col. 1) but mainly because of their higher water content, their energetic food value (col. 2) amounts to approximately $30 \%$ of the grain crops per unit of weight. If the differences in percentage edible (col. 3) are incorporated, the differences in caloric production per unit of surface appear to be smaller (col. 4). This tendency is even stronger after incorporation of the average period of vegetation (col. 5); the crops now tend to more or less the same level of production (col. 6).

The potato is also grown in subtropical regions and in mountaneous tropical regions. Its world average of production is $11.1 \mathrm{ton} / \mathrm{ha}$ or $75,000 \mathrm{Cal} . /($ ha.day of vegetation), which is much higher than any other crop. This high production, however, apparently is the result of the much more intensive cultivation in temperate regions. The average production of India for instance amounts to $7.3 \mathrm{ton} / \mathrm{ha}$ or $49,000 \mathrm{Cal}$./ (ha. day), which is of the same level as sweet potato. The same holds for maize which is grown in 
large quantities in for instance the corn belt in the USA. Should, however, only the production of developing countries be taken into account, the average production would be 1.4 ton/ha or $37,000 \mathrm{Cal}$./(ha.day), which is of the same level as rice and wheat.

Exceptional circumstances, such as for sorghum the usually marginal climatic conditions and for yam the very extensive methods of cultivation, keep these two crops clearly below the general level.

If these considerations are taken into account the following two tendencies can be found in Table 1.

- Within the group of root crops and within the group of grain crops there exist tendencies for equal productions.

- The root crops tend to a higher level of production than the grain crops (respectively $43 \times 10^{3}$ and $35 \times 10^{3} \mathrm{Cal} . /$ (ha. day).

This difference is demonstrated even more clearly by Massal and Barrau (1956) for Fiji. Their figures are given in Table 2. Unfortunately the period of vegetation of these crops in Fiji was not given, but, no doubt, sweet potato and Colocasia are very high in comparison to Table 1.

Table 2 Productions in Fiji

\begin{tabular}{lcc}
\hline Crop & tons $/$ ha & Cal. $/$ ha $\times 106$ \\
& 1.9 & 6.7 \\
Rice & 2.5 & 8.9 \\
Maize & 20.3 & 21.8 \\
Cassava & 15.2 & 14.4 \\
Sweet potato & 25.4 & 22.3 \\
Yam & 25.4 & 21.3 \\
Colocasia & \\
\hline
\end{tabular}

\section{Maximum production and rate of breeding}

The differences in average world production between the two groups of crops do not show clearly. The reasons may be first that in rice, wheat and maize more breeding has been done and secondly that these crops are mostly grown on better and usually irrigated soils. In temperate regions, however, these factors are much less important as was shown by Groenveld (1961). For temperate regions he calculated the average level of production in calories and found per ha for grains $7.2 \times 10^{6}$ Cal. and for potatoes $16.5 \times 10^{6}$ Cal., which is quite a marked difference.

By taking into account only production under optimal ecological conditions for each crop, it was attempted to make productions of different crops mutually comparable. For this purpose maximum crop yields and the rate of breeding were compiled as found in the following organizations:

- Agricultural Experiment Station, Bogor, Indonesia (APL).

- International Rice Research Institute, Los Baños, Philippines (IRRI).

- Central Rice Research Institute, Cuttack, India (CRRI).

- Institut National pour l'Étude Agronomique du Congo (INEAC).

This is, of course, only a very limited choice out of many experiment stations and 
Table 3 Maximum yields in selected experiment stations in the tropics

\begin{tabular}{|c|c|c|c|c|c|c|}
\hline \multirow[t]{3}{*}{ Crop } & \multicolumn{2}{|c|}{ tons per ha per harvest } & \multicolumn{2}{|c|}{ tons per ha per year } & \multirow{3}{*}{$\begin{array}{c}\text { Cal./(ha.day) } \\
\times 103 \\
\text { (3) }\end{array}$} & \multirow{3}{*}{$\begin{array}{c}\text { Rate } \\
\text { of } \\
\text { breeding }\end{array}$} \\
\hline & tons & source & tons & source & & \\
\hline & & (l) & & (2) & & \\
\hline Rice & 16.4 & IRRI (1965) & 26.0 & Datta et al. (1966) & 176 & $* * * *$ \\
\hline Wheat & 3.9 & INEAC (1963) & 11.7 & INEAC (1963) & 110 & $*$ \\
\hline Maize & 5.5 & INEAC (1959) & 20.0 & APL (1937) & 200 & $* *$ \\
\hline Sorghum & 4.8 & INEAC (1963) & 13.0 & INEAC (1963) & 114 & $*$ \\
\hline Cassava & 77.0 & van der Zijl (1930) & 71.1 & APL (1937) & 250 & $* *$ \\
\hline Sweet potato & 41.0 & INEAC (1963) & 65.2 & APL (1937) & 180 & * \\
\hline Banana & 39.0 & INEAC (1963) & 39.0 & INEAC (1963) & 80 & - \\
\hline
\end{tabular}

Table 4 Maximum farm yields in the U.S.A.

\begin{tabular}{lcc}
\hline Crop & tons $/$ ha & Cal. $/$ ha $\times 106$ \\
Rice & 10.6 & 26.1 \\
Wheat & 10.4 & 35.8 \\
Maize & 19.0 & 69.0 \\
Sorghum & 12.8 & 45.0 \\
\hline
\end{tabular}

confined to the tropics and to developing countries. The results of this search for maximum yields are given in Table 3 .

It should be noted that column 2 is not derived from column 1 . Neither is there any relation with the duration of growth as given in Table 1. For instance the maximum rice yield of $9.4 \mathrm{ton} / \mathrm{ha}$ was obtained in a period of vegetation of 117 days (IRRI, 1965), whereas the maximum production per unit of time of 8.0 ton per ha was reached in 98 days in the Philippines (Datta et al., 1966). Already some decades ago in Java (Indonesia) cassava (van der Zijl, 1930) reached a production of 77 tons in 487 days. The highest production per unit of time, however, also in Java, was 53.3 ton in 270 days (APL, 1937). The highest yield of sweet potato was 41 tons in 375 days (INEAC, 1963), but the maximum yield per unit of time was again in Java, with 30.2 tons in 169 days (APL, 1937).

The maximum productions of grain crops in the tropics are lower than those obtained in subtropical and temperate regions. This is illustrated in Table 4, which was calculated from figures given by Leonard and Martin (1963). Unfortunately they do not give information on the period of vegetation of these yields, but except for rice, it is clear that these periods must be longer than those used in Table 1.

\section{Potential crop yields}

If the other conditions are optimal, the production of dry matter of a crop is determined by photosynthesis and thus by sunlight. Especially in temperate regions the temperature determines the length of the growing season; in the tropics the temperature is more important for respiration than for photosynthesis (de Wit, 1965). As the growing season in the tropics is approximately twice as long as in temperate 
regions, the potential photosynthesis may be roughly estimated to be twice as large (Becking, 1962).

The gross potential dry matter production at an averagely half clouded sky is estimated by de Wit (1965) at roughly $275 \mathrm{~kg}$ carbohydrate equivalents per ha per day which equals $1100 \times 10^{3} \mathrm{Cal} /$ (ha.day). Net food production in calories is, however, much lower owing to the following three factors.

1) The crop does not immediately reach a closed stand which causes spillage of sunlight. This can be corrected to some extent by spacing the plants more closely.

2) The respiration at night uses part of the carbohydrates.

3) The percentage edible of the dry matter produced, varies between different crops. Especially the last factor may be very important, as is shown in Table 5 (Alberda, 1962; Brouwer, 1962). This table shows the explanation for the tendency that root crops produce more than grain crops. Approximately $6 \%$ of the dry matter production from grasses - through meat and milk - may be made available for human consumption. In wheat it amounts to only $36 \%$ of the dry matter production but in potatoes even more than $80 \%$ is fit for human consumption, whereas the photosynthetic efficiency of wheat and potato is just about equal (Alberda, 1962).

The highest ratio between grain and straw in rice which was found in literature is 1.6 (Vergara et al., 1966). If it is assumed that the root of rice is approximately $10 \%$, just as with wheat, the grain is $\pm 55 \%$ and the edible part $38.5 \%$ of the complete plant.

The distribution of dry matter in the plant has always been important, which can be illustrated by Table 6 for wheat. It is, however, not certain whether the breeders saw this as the real problem (van Dobben, 1962). It is clear from this table that the increase in production was not caused by a higher dry matter production but by an increase in the edible part, as a rule accompanied by a decrease in straw.

Within a variety the pattern of distribution normally seems to possess stability. It

Table 5 Dry matter production in percents per part of the plant

\begin{tabular}{lcccc}
\hline Crops & Roots & Leaf and stem & Product & Edible \\
Grasses & 40 & 60 & - & 6 \\
Rapeseed & 9 & 65 & 26 (seed) & 26 \\
Wheat & 9 & 55 & 36 (seed) & 36 \\
Peas & 10 & 40 & 50 (pod) & 50 \\
Potatoes & 3 & 15 & 82 (tuber) & 82 \\
\hline
\end{tabular}

Table 6 Total yield and grain/straw ratio of leading winter wheat varieties in The Netherlands

\begin{tabular}{lccc}
\hline Variety & Period & $\begin{array}{c}\text { Weight of straw and grain } \\
(\mathrm{kg} / \mathrm{ha})\end{array}$ & Grain/straw \\
Wilhelmina & $1902-' 32$ & 12,600 & \\
Juliana & $1934-' 47$ & 12,430 & 0.51 \\
Staring & $1948-' 61$ & 13,900 & 0.55 \\
Felix & $1958-' 61$ & 12,830 & 0.59 \\
Heines VII & $1953-' 55$ & 11,860 & 0.60 \\
& & & 0.66 \\
\hline
\end{tabular}




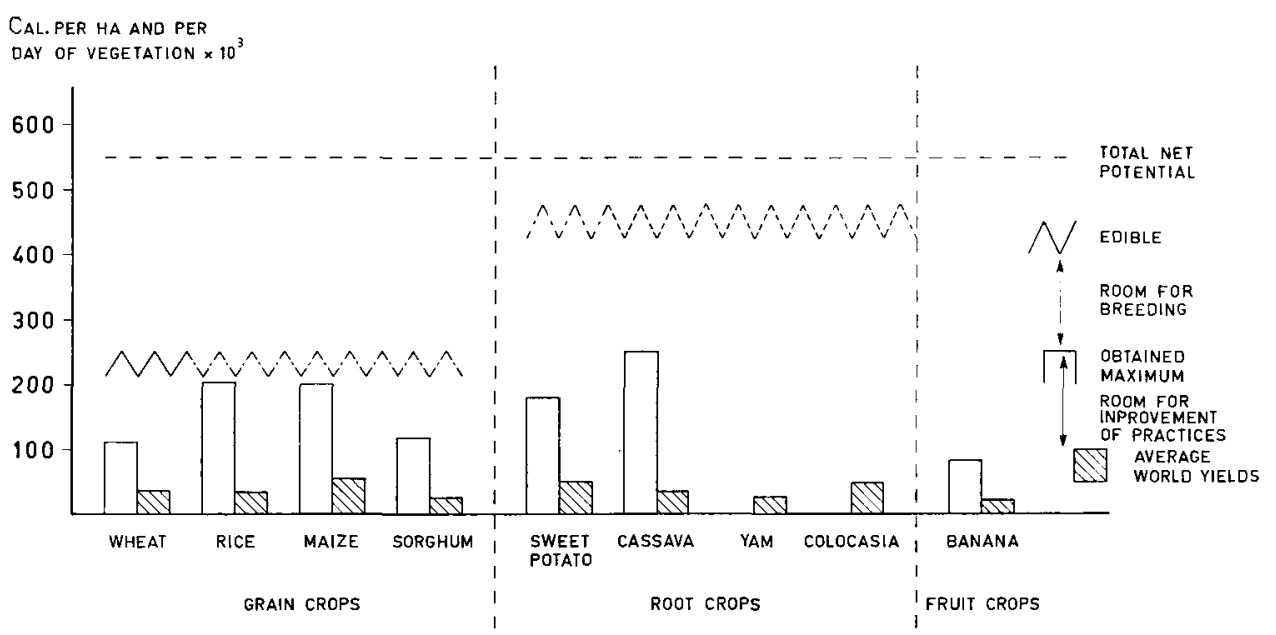

Fig. 1 Average world yields, maximum yields obtained in selected experiment stations in the tropics, and potential production of edible dry matter as compared with estimated net potential production of total dry matter for a number of tropical food crops in Calories per hectare and per day of vegetation.

is possible to change this pattern by means of breeding but it seems fairly certain that grain crops will never reach the level of the root crops. For, even if they possess a more concentrated food, plants producing their edible parts above the soil are likely to need more dry matter for bearing than plants that grow these parts in the soil. The higher the fruit above the surface the more dry matter will be needed.

In Fig. 1 the world averages of yields from Table 1, the maximum yields from Table 3 and a rough estimate of the highest possible yields are brought together. The average net potential production of dry matter was estimated at half the gross potential production, i.e. at $550 \times 10^{3} \mathrm{Cal} . /$ (ha.day). Based on wheat for grains and potato for root crops the pattern of distribution of edible dry matter was calculated in at its probable maximum.

These rough estimates may meet the following objections. First it is not known whether all these crops have the same photosynthetic efficiency. In case of the grain crops and the sweet potato this probably would not cause large discrepancies. But it might be completely different for the other root crops and the banana. Secondly it is not known whether the pattern of distribution of the edible dry matter is comparable within each group of crops. Again this seems less important among the grain crops, but among the root crops there might be more diversion and in this respect nothing is yet known of the banana. These uncertainties are made visible in Fig. 1 by the way in which the various lines are drawn.

These estimates of the highest possible yields are not absolute maxima as first they may be influenced by breeding and selection and secondly the yield may be considerably more in exceptionally favorable regions. The diagram shows clearly that root crops probably have a far higher production capacity than grain crops and also that the root crops are far behind in breeding and selection in the experiment stations mentioned. 
Table 7 Composition per 100 calories edible portion

\begin{tabular}{|c|c|c|c|c|c|c|c|c|}
\hline & $\begin{array}{l}\text { Protein } \\
\quad(g)\end{array}$ & $\begin{array}{c}C a \\
(m g)\end{array}$ & $\begin{array}{c}F e \\
(m g)\end{array}$ & $\begin{array}{l}\text { Vit. A } \\
\text { (I.U.) }\end{array}$ & $\begin{array}{c}\text { Thiamine } \\
\quad(m g)\end{array}$ & $\begin{array}{c}\text { Riboflavin } \\
\text { (mg) }\end{array}$ & $\begin{array}{c}\text { Nicotin } \\
\text { amid } \\
(m g)\end{array}$ & $\begin{array}{c}\text { Ascorbic } \\
\text { acid } \\
(m g)\end{array}$ \\
\hline Rice & 2.0 & 1.4 & 0.28 & \pm 0 & 0.017 & 0.0085 & 0.28 & 0 \\
\hline Wheat & 3.2 & 5.8 & 0.73 & \pm 0 & 0.087 & 0.023 & 0.58 & 0 \\
\hline Maize & 2.8 & 3.3 & 0.69 & $30-170$ & 0.096 & 0.036 & 0.55 & 0 \\
\hline Sorghum & 2.9 & 9.0 & 1.26 & \pm 0 & 0.14 & 0.034 & 0.98 & 0 \\
\hline Sweet potato & $0.35-2.5$ & 21.9 & 0.90 & $0-3500$ & 0.090 & 0.035 & 0.61 & 26 \\
\hline Cassava & 0.46 & 16.3 & 0.65 & \pm 0 & 0.46 & 0.019 & 0.46 & 20 \\
\hline Yam & 1.9 & 9.6 & 1.1 & $0-190$ & 0.096 & 0.029 & 0.38 & 9 \\
\hline Colocasia & 1.8 & 22.1 & 0.9 & \pm 0 & 0.09 & 0.027 & 0.9 & 45 \\
\hline Banana & 0.8 & 5.5 & 0.39 & 80 & 0.039 & 0.039 & 0.55 & 16 \\
\hline
\end{tabular}

Table 8 Protein content of edible leaves of root crops

\begin{tabular}{lll}
\hline Sweet potato & $5 \%$ & (Platt, 1965) \\
Cassava & $6-10 \%$ & (Terra, 1966) \\
Yam & leaves not eaten \\
Colocasia & $3.5-7 \%$ & (Terra, 1966)
\end{tabular}

For these two reasons it seems therefore important to pay more attention to breeding and selection of root crops.

\section{The food quality}

It is often said that the food produced by root crops is of an inferior quality. The root crops are especially thought to contain less proteins than grain crops. It is true that grain crops contain $7-11 \%$ proteins per $100 \mathrm{~g}$ edible portion against the root crops only $0.4-2.8 \%$. But for determination of food quality the energetic food value has to be the starting point, i.e. the composition should be calculated per 100 calories edible portion. This is done, after Platt (1965), in Table 7.

This way of calculation shows the differences in protein contents between root crops and grain crops to be considerably smaller. Rice, the most important tropical food crop, does not compare favorably with the root crops. It actually contains a little more proteins than most root crops but in every other respect of food quality the root crops are superior to rice. This is also the case with the other grain crops; they rate somewhat higher in protein but lower in most other respects. Only cassava and banana have a considerably smaller protein content. And in the field of protein contents of root crops breeding is likely to be very succesful.

It may therefore be concluded that the grain crops are not so very important from the food quality point of view as is often suggested. Most important in grain crops is their storage quality. Especially polished rice can be kept long, but precisely polished rice is poor in food quality owing to a shortage in thiamin (which causes beriberi) and a shortage in vitamin $\mathbf{A}$ (blindness).

Moreover, most root crops have edible leaves, with considerable protein contents. Some figures in this field are compiled in Table 8 . It can easily be seen that con- 
sumption of such leaves would constitute an increase in protein intake. This is especially important in the case of cassava.

\section{Conclusions}

In general the root crops have a far higher potential production than grain crops. Moreover, in experiments the grain crops - especially rice and maize - are already close to their potential yields which means that improvement of these crops has only limited possibilities. The root crops, however, show larger promise because of their higher potential production. Therefore, much more attention in breeding and selection should be paid to the root crops, not only in the field of higher production but also with respect to higher protein contents.

In Fig. 1 attention is focused on another problem, which is, however, beyond the scope of this paper. The large discrepancy between obtained maximum and the average world yields shows that immediate relief for the existing world food shortage should not be expected from breeding and selection but mainly from improvement of practices of cultivation.

Even without such improvement the most widely grown root crops, i.e. sweet potato and cassava, already compare favorably with most grain crops. Therefore, provided the climatic conditions are right and there are no problems of storage and transport, root crops are to be preferred above grain crops.

\section{References}

Alberda, Th., 1962. Actual and potential production of agricultural crops. Neth. J. Agr. Sci., 10 : 325-333.

APL, 1937. Verslagen 1929-1936. Algemeen Proefstation voor de landbouw (APL), Landbouwk. Inst., Landbouwk. Onderafd., Bogor, Indonesia.

Becking, J. H., 1962. Potential and actual productivity of stem wood in forestry. Neth. J. Agr. Sci., $10: 354-360$.

Brouwer, R., 1962. Distribution of dry matter in the plant. Neth. J. Agr. Sci., 10: 361-376.

CRRI, 1960. Central Rice Research Institute, Cuttack. Ann. Rept. 1957-1958, India.

Datta, S. K. de, Moomaw, J. C. and Dayrit, R. S., 1966. Nitrogen response and yield potential of some rice varietal types in the tropics. Intern. Rice Comm. News Letter, 15 (3) : 16-17.

Dobben, E. H. van, 1962. Influence of temperature and light conditions on dry matter distribution, development rate and yield in arable crops. Neth. J. Agr. Sci., 10: 377-389.

FAO, 1964. Production Yearbook 1963. FAO, Rome, $516 \mathrm{pp}$.

Groenveld, D., 1961. Investment for food. North Holland Publ. Cy., Amsterdam, 146 pp.

INEAC, 1959. Rapport annuel pour l'Exercice 1958. Institut National pour l'Étude agronomique, 529 pp.

INEAC, 1963. Rapport du Secteur du Ruanda-Burundi pour les Exercices 1960, 1961 et 1962. Institut National pour l'Étude Agronomique du Congo, $168 \mathrm{pp}$.

IRRI, 1965. International Rice Research Institute. Ann. Rept. 1964, Manilla, 335 pp.

Leonard, W. H. and Martin, J. H., 1963. Cereal crops. McMillan, New York, 823 pp.

Massal, E. and Barrau, J., 1956. Food plants of the South Sea islands. Tech. Paper, South Pacific Comm., Noumea, No. 94, 52 pp.

Platt, B. S., 1965. Tables of representative values of foods commonly used in tropical countries. Medical Res. Council, Spec. Rept. Ser., London, No. 302, 46 pp.

Terra, G. J., 1966. Tropical vegetables. Commun. Koninkl. Inst. Tropen, Amsterdam, No. 54e, $107 \mathrm{pp}$.

Vergara, B. S., Tanaka, A., Lilis, R. and Puranabhavung, S., 1966. Relationships between growth duration and grain yields of rice plants. Soil Sci. Plant Nutr., 12: 31-39.

Wit, C. T. de, 1965. Photosynthesis of leaf canopies. Versl. Landbouwk. Onderz., No. 663, 57 pp.

Zijl, C. E. van der, 1930. Verbetering der cassave cultuur door middel van proefvelden. Thesis, Agric. Univ., Wageningen, $127 \mathrm{pp}$. 